Article

\title{
The Role of NiO in Reactive Adsorption Desulfurization Over $\mathrm{NiO} / \mathrm{ZnO}-\mathrm{Al}_{2} \mathrm{O}_{3}-\mathrm{SiO}_{2}$ Adsorbent
}

\author{
Feng Ju ${ }^{\circledR}$, Miao Wang ${ }^{\circledR}$, Tian $W u$ and Hao Ling * \\ State Key Laboratory of Chemical Engineering, East China University of Science and Technology, \\ Shanghai 200237, China; jufeng@mail.ecust.edu.cn (F.J.); wangmiao@mail.ecust.edu.cn (M.W.); \\ wutian@mail.ecust.edu.cn (T.W.) \\ * Correspondence: linghao@ecust.edu.cn; Tel.: +86-21-64252328
}

Received: 17 November 2018; Accepted: 8 January 2019; Published: 14 January 2019

\begin{abstract}
The reactive adsorption desulfurization (RADS) of a model gasoline $n$-hexane containing thiophene was carried out with a $\mathrm{NiO} / \mathrm{ZnO}-\mathrm{Al}_{2} \mathrm{O}_{3}-\mathrm{SiO}_{2}$ adsorbent in $\mathrm{N}_{2}$ and $\mathrm{H}_{2}$, respectively. A declining RADS trend has been observed in $\mathrm{N}_{2}$, without the presence of $\mathrm{H}_{2}$, indicating that $\mathrm{NiO}$ is sulfurized and exhibits activity for RADS. TPR and XPS results presented NiO in the adsorbent is hard to be reduced because of the powerful interaction between $\mathrm{NiO}$ and the support. The sulfurization of $\mathrm{NiO}$ into $\mathrm{NiS} x$ is a primary condition for the RADS process, the same as the presulfurization of hydrotreating catalyst, while metallic $\mathrm{Ni}$ is an intermediate reduction product of NiSx . Results of a low RADS temperature at $300^{\circ} \mathrm{C}$, much lower than the reduction temperature of $\mathrm{NiO}$, suggest that $\mathrm{NiO}$ plays an important role. Based on assumption of $\mathrm{NiO}$ as the main active component, the RADS could reduce the reaction temperature and energy consumption significantly. The participation of hydrogen and $\mathrm{n}$-hexane in pretreatment conducted at $420^{\circ} \mathrm{C}$ contributes to the activation of adsorbent. Also, these methods of pretreatment improved the desulfurization performance under the reaction temperature of $300^{\circ} \mathrm{C}$.
\end{abstract}

Keywords: reactive adsorption desulfurization; $\mathrm{NiO}$; metallic $\mathrm{Ni}$; $\mathrm{NiO} / \mathrm{ZnO}-\mathrm{Al}_{2} \mathrm{O}_{3}-\mathrm{SiO}_{2}$ adsorbent

\section{Introduction}

Stringent environmental regulations have forced refineries to develop new process for deep desulfurization of fossil oil [1]. The reactive adsorption desulfurization process (RADS) is an effective measure of ultradeep desulfurization of fossil fuel [2,3]. The S Zorb process, invented by Concoco Philips Petroleum Co., proposes an effective way for producing ultralow-sulfur diesel and gasoline at a comparably low $\mathrm{H}_{2}$ pressure (0.7-2.1 MPa). The adsorbent used in the process consists of $\mathrm{Ni} / \mathrm{NiO}$ and $\mathrm{ZnO}$, which remove the sulfur atoms from organic compounds containing sulfur. Sulfur atoms from sulfur compounds are adsorbed into the adsorbent and react with the adsorbent, and the hydrocarbon part of the molecule is released back into the product stream [4-7].

Many publications discussed the mechanism of RADS over Ni/ZnO-based adsorbent [8-13]. Babich and Moulijin [14] first proposed a mechanism of RADS over Ni/ZnO-based adsorbent. They presented that $\mathrm{NiO}$ would be reduced to metallic $\mathrm{Ni}$ or $\mathrm{Ni} 0$ with the presence of $\mathrm{H}_{2}$. Then, sulfur atoms will react with $\mathrm{Ni}^{0}$ atoms and lead to the formation of NiSx. The formed NiS $x$ will be in situ reduced to Ni0. Meanwhile, released $\mathrm{H}_{2} \mathrm{~S}$ will react immediately with $\mathrm{ZnO}$ to form $\mathrm{ZnS}$. Whether $\mathrm{NiS} x$ can be converted to $\mathrm{Ni}^{0}$ by $\mathrm{H}_{2}$ determines the stability of the effect of sulfur removal of sorbents. Huang et al. [15] proposed a reaction mechanism of RADS processes carried out in different atmospheres and the role of $\mathrm{H}_{2}$ in the desulfurization process over $\mathrm{Ni} / \mathrm{ZnO}$. They found 
that hydrogen can effectively stimulate the sulfur transfer during reactive adsorption desulfurization of oil product over $\mathrm{Ni} / \mathrm{ZnO}$. In the case of the RADS process, $\mathrm{NiO}$ could be sulfurized into $\mathrm{Ni}_{3} \mathrm{~S}_{2}$ or $\mathrm{NiS} x$ although presulfurization is not employed. Bezverkhyy [16] found that, in the case of $\mathrm{Ni} / \mathrm{SiO}_{2}$, a relatively slower bulk transformation into $\mathrm{Ni}_{3} \mathrm{~S}_{2}$ always follows after a rapid surface reaction. Okamoto claimed that $\mathrm{Ni}_{3} \mathrm{~S}_{2}$ is a stable state of nickel sulfide [17]. The reason may be that $\mathrm{Ni}_{3} \mathrm{~S}_{2}$ is favorable in the $\mathrm{H}_{2}$ atmosphere. The formation of NiS can hardly happen before sulfur contained in the nickel sulfide is transmitted into $\mathrm{ZnO} . \mathrm{Ni}_{3} \mathrm{~S}_{2}$ is probably more stable than NiS under current circumstance [18]. In another publication of Bezverkhyy [19], their results indicated that surface ZnS layer was formed firstly, and the kinetics of sulfidation at different steps were dependent on the reaction conditions, and the first one is fast sulfur chemisorption. $\mathrm{NiO} / \mathrm{ZnO}$ adsorbents can be spent in the RADS process of thiophene without reductive pretreatment by hydrogen [18]. It was also mentioned that hydrogen pretreatment hardly had effect on desulfurization. Tang et al. [13] studied the powerful metal-support interactions (SMSI) between nickel and zinc oxide particles of $\mathrm{Ni} / \mathrm{ZnO}$ catalyst. They reduced $\mathrm{NiO} / \mathrm{ZnO}$ catalyst in a temperature range from $350{ }^{\circ} \mathrm{C}$ to $500{ }^{\circ} \mathrm{C}$, and found that the reduction peak of $\mathrm{NiO}$ in the $\mathrm{NiO} / \mathrm{ZnO}$ sample shifted to $370{ }^{\circ} \mathrm{C}$, which suggests that $\mathrm{NiO}$ in $\mathrm{NiO} / \mathrm{ZnO}-\mathrm{Al}_{2} \mathrm{O}_{3}-\mathrm{SiO}_{2}$ adsorbent is hard to be reduced under lower reaction temperature.

From the review presented above, there is a good deal of conflict about the desulfurization mechanism of $\mathrm{NiO}$ based adsorbents. The hydrodesulfurization (HDS) catalysts are commonly sulfide $\mathrm{Ni}-\mathrm{Mo} / \mathrm{Al}_{2} \mathrm{O}_{3}$ and $\mathrm{Co}-\mathrm{Mo} / \mathrm{Al}_{2} \mathrm{O}_{3}$. Presulfurization is an essential process for activation of HDS catalyst in the oxidic form. In presulfurization, a sulfurizing agent such as organic polysulfide is used to sulfurize the pre-loaded catalyst in a reactor [20]. This rises a question whether NiO could act alone as the active component for RADS. The presulfurization process of hydrotreating catalyst showed that $\mathrm{NiO}$ could be sulfurized alone to form $\mathrm{NiS} x$. Wang [21] compared a presulfurized $\mathrm{NiO} / \gamma-\mathrm{Al}_{2} \mathrm{O}_{3}$ catalyst with $\mathrm{NiSO}_{4} / \gamma-\mathrm{Al}_{2} \mathrm{O}_{3}$ catalysts with different nickel loadings, and found that $\mathrm{NiSO}_{4}$ can be partially self-sulfided to NiS $x$ by hydrogen. They considered that NiS $x$ species was a real active component in the HDS reaction. This is very similar to the reaction of $\mathrm{NiO}$ with thiophene to form NiS $x$ in RADS process.

In this work, the RADS of a model gasoline, n-hexane containing thiophene, was conducted over the $\mathrm{NiO} / \mathrm{ZnO}-\mathrm{Al}_{2} \mathrm{O}_{3}-\mathrm{SiO}_{2}$ adsorbent in $\mathrm{N}_{2}$ and $\mathrm{H}_{2}$, respectively. The reduced and unreduced adsorbents were respectively characterized by XRD, TPR, and X-ray photoelectron spectroscopy (XPS). Desulfurization performance at lower temperature was also researched. After the evaluation of RADS experiments and characterization of adsorbents, various pretreatment experiments were conducted to study the activation of adsorbents and the effects of pretreatments on RADS process.

\section{Results and Discussion}

\subsection{RADS Performance under Different Atmospheres}

In a first approach, the adsorption performances of three conditions were shown in Figure 1. The $\mathrm{H}_{2}$ reducing pretreatment method has a $\mathrm{H}_{2}$ flow rate of $140 \mathrm{~mL} / \mathrm{min}$ under $2.0 \mathrm{MPa}$ and a temperature of $440{ }^{\circ} \mathrm{C}$ for $2 \mathrm{~h}$. The other two experiments did not employ the $\mathrm{H}_{2}$ reducing pretreatment. $\mathrm{H}_{2}$ or $\mathrm{N}_{2}$, as carrier gas, was introduced into the reactor together with model gasoline, respectively. Experiments designed for this comparison were carried out with the same model components and reaction temperature. Under these conditions, the RADS performances, expressed as $\mathrm{mL}$ of gasoline per $\mathrm{g}$ of sorbent, are shown in Figure 1. From this figure, it is evident that samples in $\mathrm{N}_{2}$ displayed a declining sulfur removal trend with the volume of effluent gasoline. 


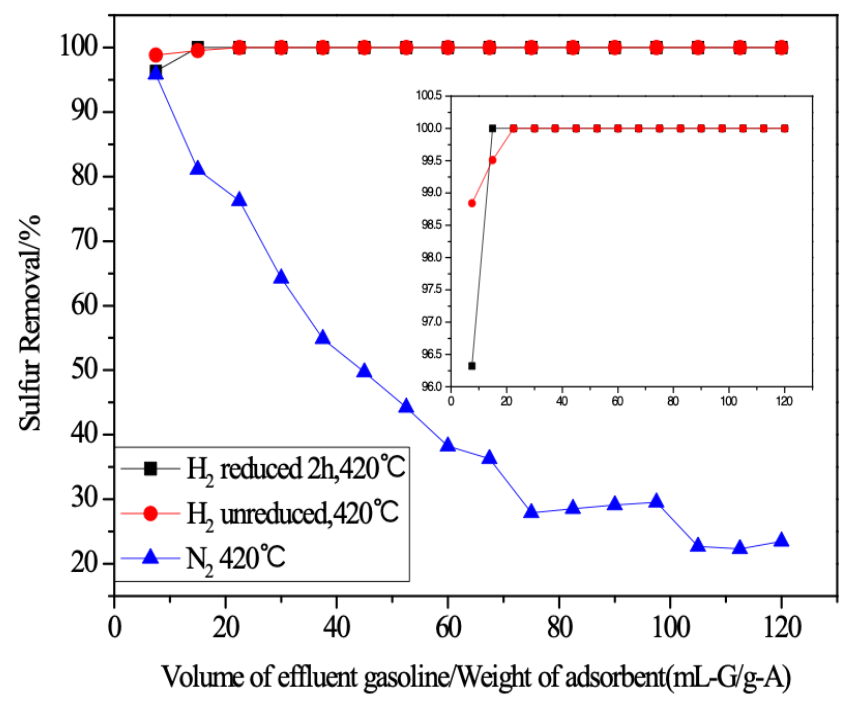

Figure 1. Desulfurization performance of reduced and unreduced adsorbent under different atmospheres.

The declining trend using $\mathrm{N}_{2}$ as carrier gas disclosed that the sulfurization of $\mathrm{NiO}$ could happen without the presence of $\mathrm{H}_{2}$. In another word, the sulfur atom is captured from the thiophene molecule and is fixed by the sorbent without $\mathrm{H}_{2}$. Small amount of hydrocarbons will form carbon deposit on the surface of the adsorbent, which is a reason of the drop of the sulfur removal. Figure 1 shows that the sulfur removal rate still keeps at $25 \%$ in nitrogen atmosphere after treating model gasoline about $120 \mathrm{~mL}-\mathrm{G} / \mathrm{g}$-A. Though the sulfur removal rate is much lower compared to which in $\mathrm{H}_{2}$ atmosphere, $\mathrm{NiO}$ shows considerable activity in the reaction with thiophene in $\mathrm{N}_{2}$.

Figure 1 presents that the sulfur removal ratio in $\mathrm{H}_{2}$ is much higher than that in $\mathrm{N}_{2}$. However, the $\mathrm{H}_{2}$ reduced adsorbent does not have any advantage over the unreduced adsorbent. This is in agreement with the observations by Huang [17]. There is no evidence of a breakthrough in $\mathrm{H}_{2}$, even when the test is progressed to a volume of $120 \mathrm{~mL}-\mathrm{G} / \mathrm{g}-\mathrm{A}$. As $\mathrm{H}_{2}$ can considerably improve the effect of desulfurization, desulfurization performance in $\mathrm{H}_{2}$ is much better than that in $\mathrm{N}_{2}$. The presence of hydrogen obviously reduces the formation of surface carbon deposits during the desulfurization process [22-24].

\subsection{XRD Characterization}

Figure 2 shows the XRD patterns of used adsorbents under different RADS conditions. According to the patterns, $\mathrm{ZnS}$ characteristic diffraction peaks appeared in all cases. The mobility of sulfur from $\mathrm{NiS} x$ to $\mathrm{ZnO}$ is the main reason of the formation of $\mathrm{ZnS}$. The peaks of $\mathrm{ZnS}$ in $\mathrm{N}_{2}$ cases also proved that the desulfurization process could happen in $\mathrm{N}_{2}$. Another phenomenon is that $\mathrm{Ni}^{0}$ could not be detected by XRD in all cases. These results suggest that there should be another active component playing an important role in RADS besides $\mathrm{Ni}^{0}$. 


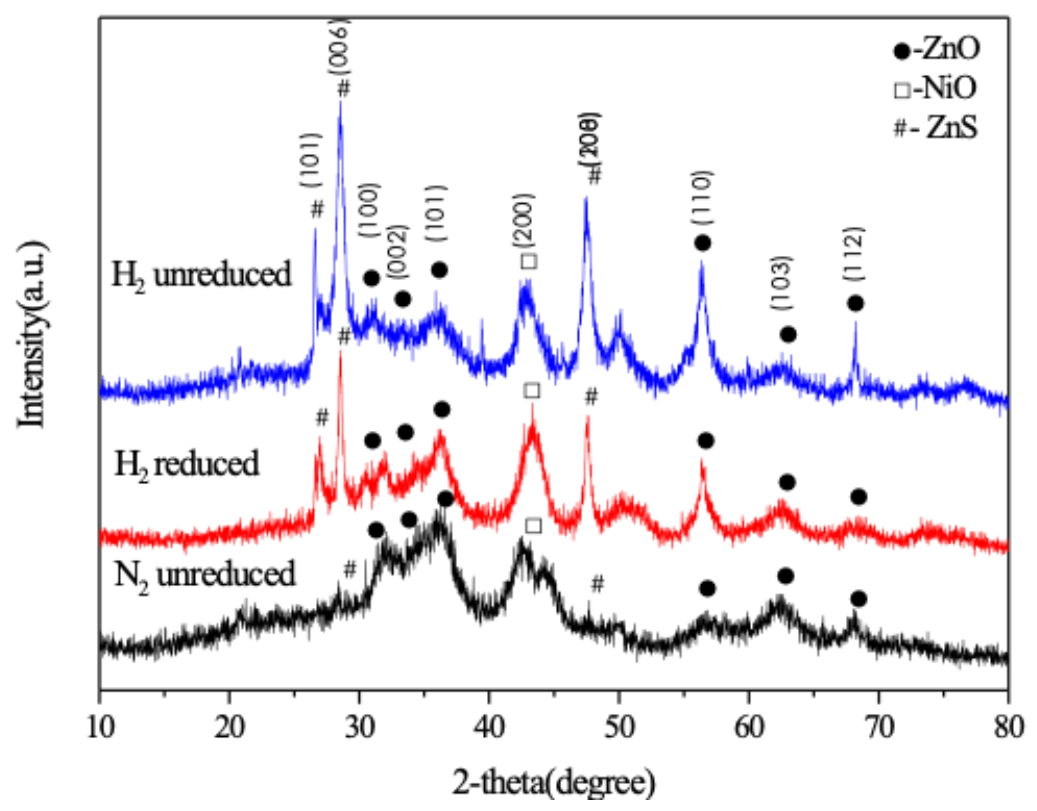

Figure 2. X-ray photoelectron spectroscopy (XPS) analysis of adsorbents after reaction.

Normally, $\mathrm{NiO}$ could be reduced at about $290{ }^{\circ} \mathrm{C}$. Moreover, Shamskar et al. [25] found that the reduction temperature of $\mathrm{NiO}-\mathrm{Al}_{2} \mathrm{O}_{3}$ catalyst would increase with the calcination temperature increasing. When calcination temperature is over $600{ }^{\circ} \mathrm{C}$, the reduction temperature of $\mathrm{NiO}-\mathrm{Al}_{2} \mathrm{O}_{3}$ catalyst is over $700{ }^{\circ} \mathrm{C}$. For the adsorbent in this study, the temperature of calcination is $500{ }^{\circ} \mathrm{C}$, indicating that the reduction temperature may be over $600{ }^{\circ} \mathrm{C}$. Zielinski [26] attributed the peak existing between $300-500{ }^{\circ} \mathrm{C}$ to the reduction of nickel oxide which is not bound with the support, referring to it as "free" $\mathrm{NiO}$, and the reduction peak existing between $500-800{ }^{\circ} \mathrm{C}$ to nickel that had already bound with the support forming $\mathrm{NiAl}_{2} \mathrm{O}_{4}$. In XRD patterns, the absence of $\mathrm{SiO}_{2} \mathrm{or} \mathrm{Al}_{2} \mathrm{O}_{3}$ peaks indicate that both of them are in amorphous states in the sorbents. $\mathrm{SiO}_{2}$ was used to dilute the effect of the formation of $\mathrm{NiAl}_{2} \mathrm{O}_{4}$. The reason behind this is possibly that $\mathrm{SiO}_{2}$ has a dilution effect on the active sites of $\mathrm{Al}_{2} \mathrm{O}_{3}$. With an excess amount of $\mathrm{SiO}_{2}$ loaded on the support, the acidity decreases as a result. This implies that $\mathrm{SiO}_{2}$ could strengthen the adsorption of the sulfur compounds.

As is shown in Figure 2, $\mathrm{Ni}$ and $\mathrm{Zn}$ elements exist in the form of metallic oxides. The diffraction peaks $\left(2 \theta=43.2^{\circ}, 75.5^{\circ}\right)$ are attributed to $\mathrm{NiO}$ in fresh or reduced sorbents, confirming an existence of "free" nickel oxide. There is no evidence in the positions $\left(2 \theta=44.5^{\circ}, 76.1^{\circ}\right)$ where Ni locates.

According to this phenomenon, it seems that $\mathrm{NiO}$ may not be reduced to $\mathrm{Ni}$ under our experimental condition. Tang characterized reduced and unreduced $\mathrm{NiO} / \mathrm{ZnO}$ sorbents by XRD in his survey and reached a similar conclusion [13]. Moreover, the result of Ryzhikov's [18] research on the effect of hydrogen pretreatment on desulfurization shows that despite any improvement, such process of hydrogenation may lead to the formation of $\mathrm{Ni}-\mathrm{Zn}$ alloys, which in some extend declines the sulfur removal ratio. Also, $\mathrm{NiO}$ should be considered as a probable active component.

\subsection{EDS Results}

Figure 3 presents the EDS results by which we could investigate whether surface element distributions could be changed after reduction and desulfurization. 


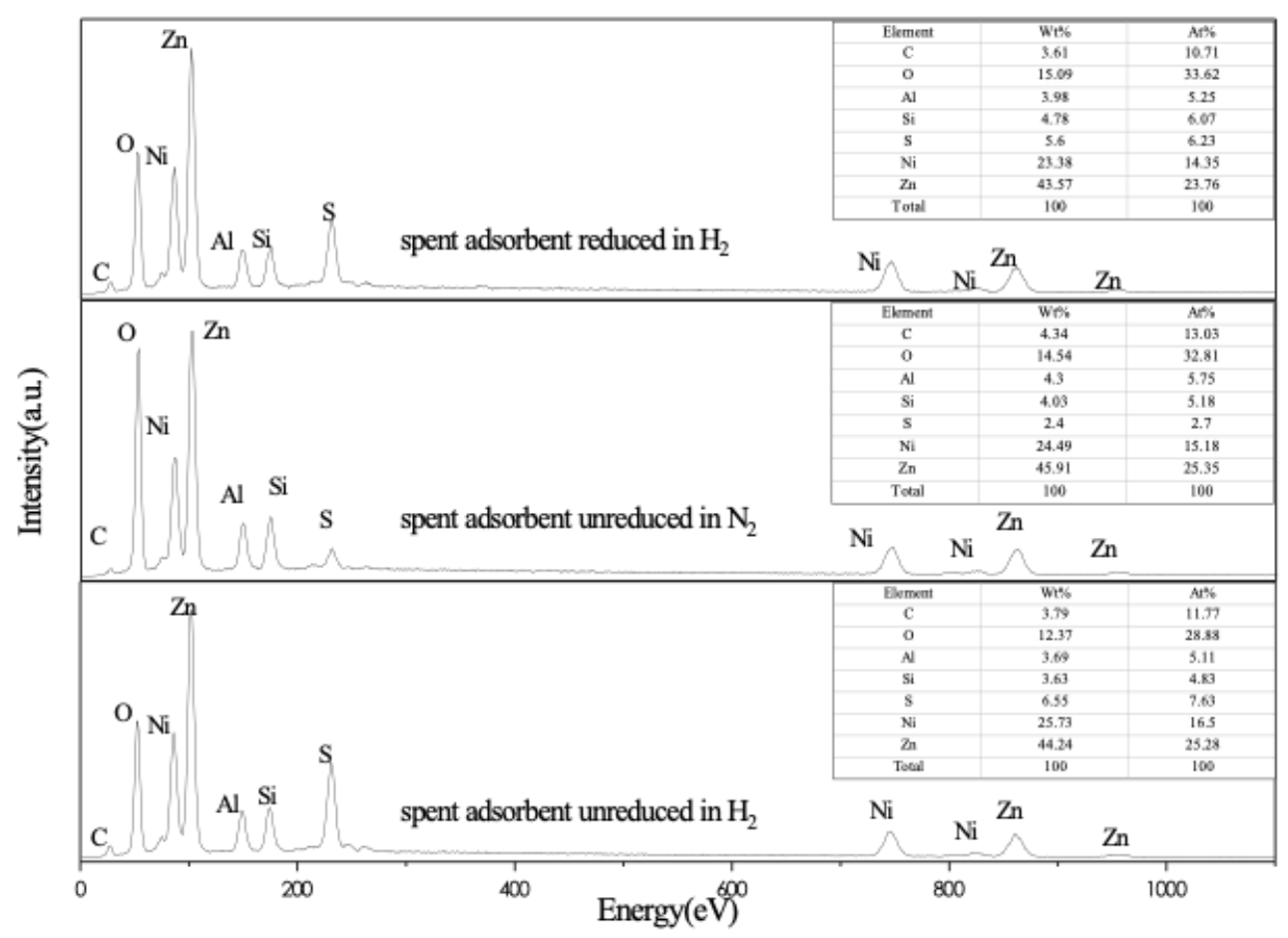

Figure 3. EDS analysis of surface element distributions of adsorbents before and after reaction.

In Figure 3, the contents of sulfur increase by $6.55 \mathrm{wt} \%$ and $5.60 \mathrm{wt} \%$ on unreduced and reduced spent sorbents in hydrogen, respectively. Both of them are higher than that appeared of spent sorbent in nitrogen. This result matches well with the desulfurization effect shown in Figure 1. The contents of carbon increase by $4.34 \mathrm{wt} \%$ after the reaction on unreduced sorbents applied in $\mathrm{N}_{2}$, slightly higher than $3.79 \mathrm{wt} \%$ and $3.61 \mathrm{wt} \%$ on unreduced and reduced sorbents in hydrogen. For one thing, this contrast means that hydrogen could obviously inhibit the formation of surface carbon. For another thing, hydrogen pretreatment may attribute nothing to promote the desulfurization ability of adsorbents.

\section{4. $\mathrm{H}_{2}$-Temperature Programmed Reduction (TPR) Characterization}

Figure 4 presents the $\mathrm{H}_{2}$-TPR profiles of $\mathrm{ZnO}-\mathrm{Al}_{2} \mathrm{O}_{3}-\mathrm{SiO}_{2}$ support (a), $\mathrm{NiO}$ (b) and fresh adsorbent (c). The support has a very weak $\mathrm{H}_{2}$ consumption signal at the temperature ranging from 450 to $650{ }^{\circ} \mathrm{C}$. For NiO, there's a sharp hydrogen consumption peak at about $290^{\circ} \mathrm{C}$. For the fresh adsorbent, the reduction peak of nickel oxide in $\mathrm{NiO} / \mathrm{ZnO}-\mathrm{Al}_{2} \mathrm{O}_{3}-\mathrm{SiO}_{2}$ adsorbent is shifted to $520^{\circ} \mathrm{C}$. According to Tang's research [13], the powerful metal-support interactions (SMSI) between nickel and zinc oxide particles of $\mathrm{Ni} / \mathrm{ZnO}$ could raise the reduction temperature of nickel oxide in $\mathrm{NiO} / \mathrm{ZnO}$ to $370{ }^{\circ} \mathrm{C}$, implying that there is a powerful interaction between nickel oxide and the support. This probable interaction may make $\mathrm{NiO}$ much more difficult to be reduced. It can be inferred from the profiles that $\mathrm{NiO}$ contained in the fresh adsorbent seems unlikely to be reduced to $\mathrm{Ni}^{0}$ at $420{ }^{\circ} \mathrm{C}$. Considering the excellent performance of desulfurization in our study, $\mathrm{NiO}$ may play the role of an active component in place of nickel. 


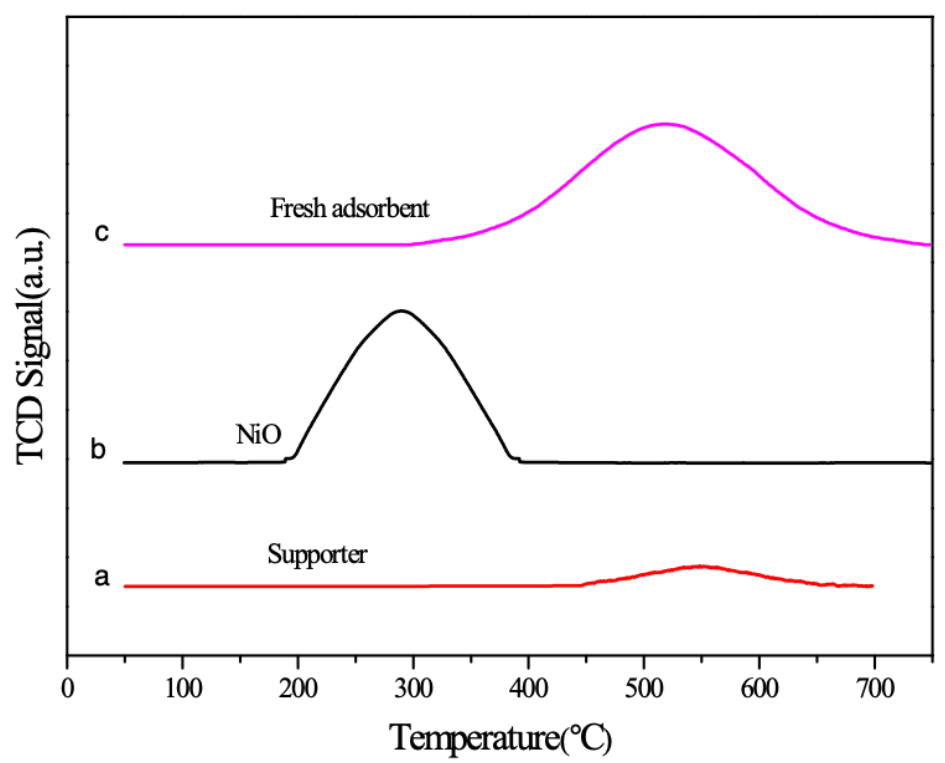

Figure 4. $\mathrm{H}_{2}$-TPR (temperature programmed reduction) of support (a), $\mathrm{NiO}$ (b) and fresh adsorbent (c).

\subsection{X-Ray Photoelectron Spectroscopy (XPS) Characterization}

XPS spectra was adopted to characterize fresh, reduced and used adsorbents, shown in Figure 5. All XPS spectra were calibrated with the C1s peak at $285.4 \mathrm{eV}$ [27]. According to Figure 5, zinc, nickel, and sulfur elements are at the $2 p$ energy level. After the desulfurization, sulfur and carbon elements can be probed on the surface of adsorbents. It indicates that sulfur elements are adsorbed well and carbon deposits are generated on the surface of the adsorbents. For the adsorbents which have been used in nitrogen, the weak peak of sulfur shows the poor desulfurization performance in $\mathrm{N}_{2}$.

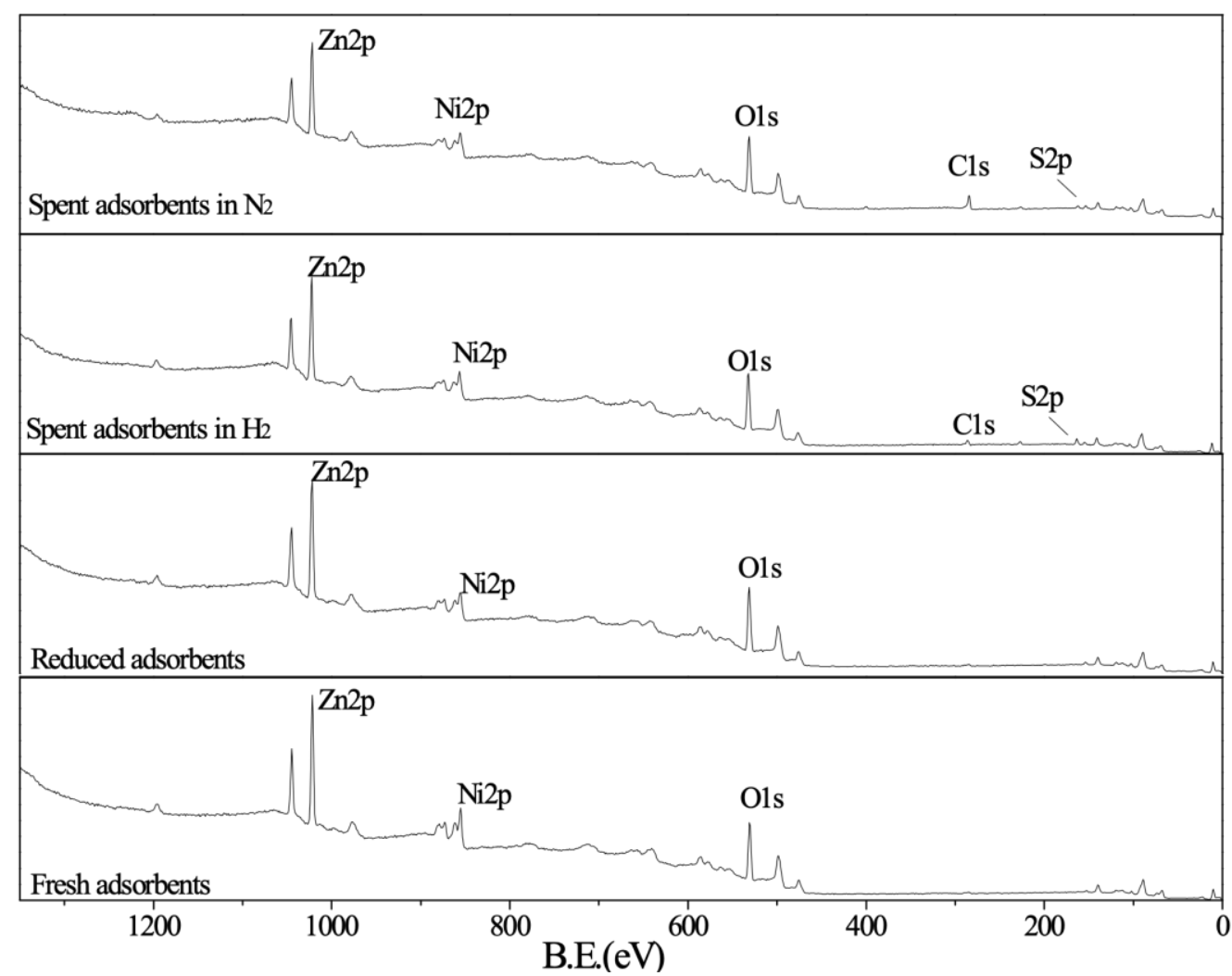

Figure 5. X-Ray Photoelectron Spectroscopy (XPS) spectra of fresh, reduced and sulfurized adsorbent. 
Narrow XPS spectra of sulfur, carbon, nickel, and zinc are shown in Figure 6. Figure 6a shows narrow XPS spectra of C1s. The C1s peaks of adsorbents after desulfurization are much stronger than the reduced adsorbent $\mathrm{C} 1 \mathrm{~s}$ peak, which indicates the formation of carbon deposits. However, compared with the peaks in Figure 5, the peak of C1s is not obvious. It means that there are not many carbon deposits on the surface, which is consistent with EDS results.

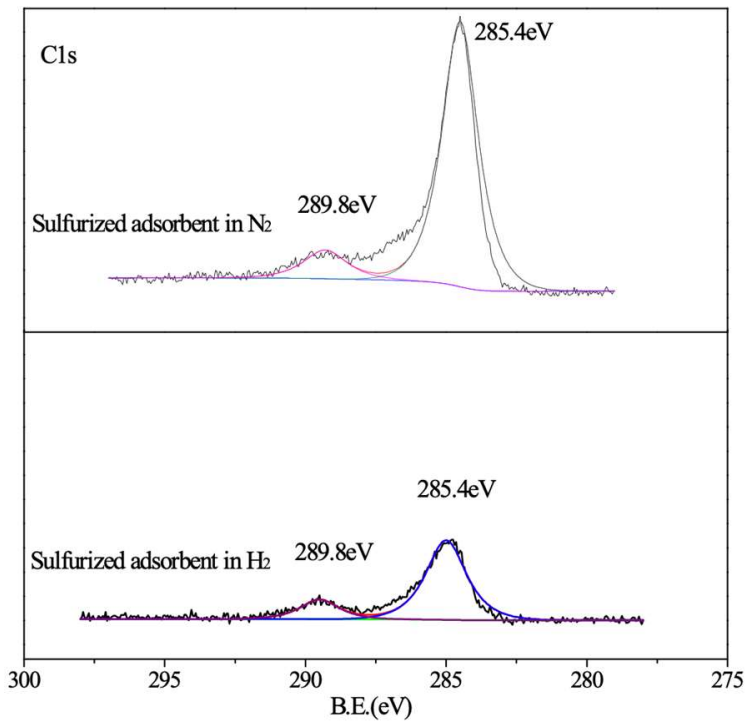

(a)

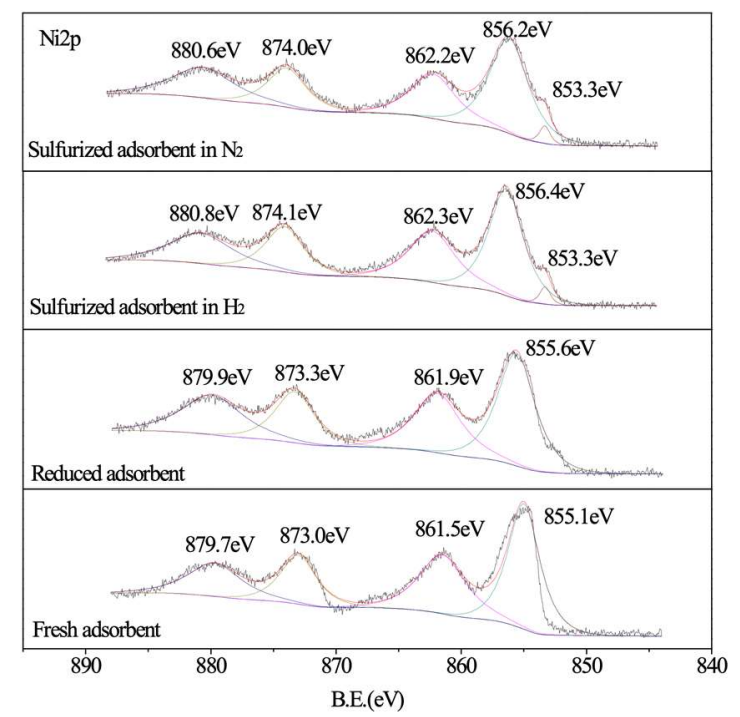

(c)

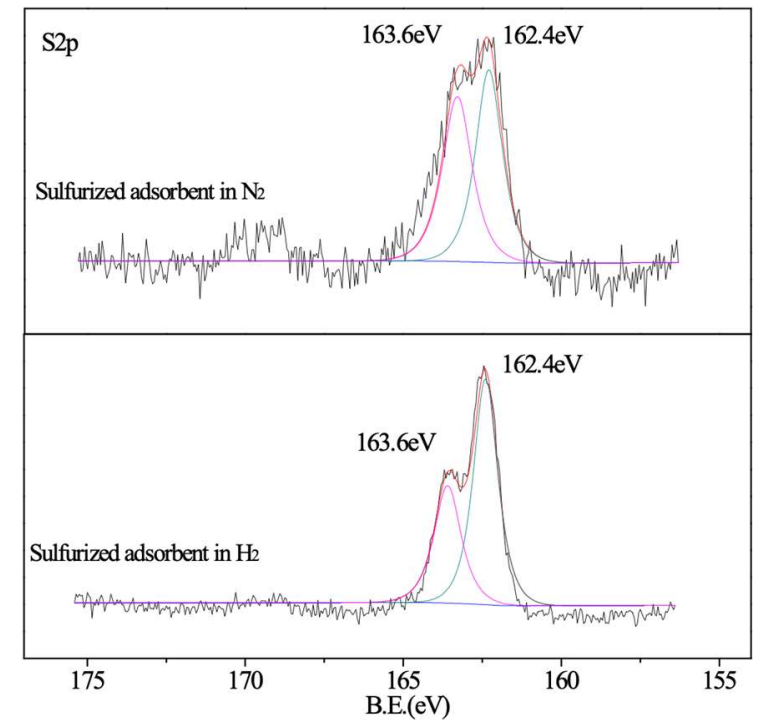

(b)

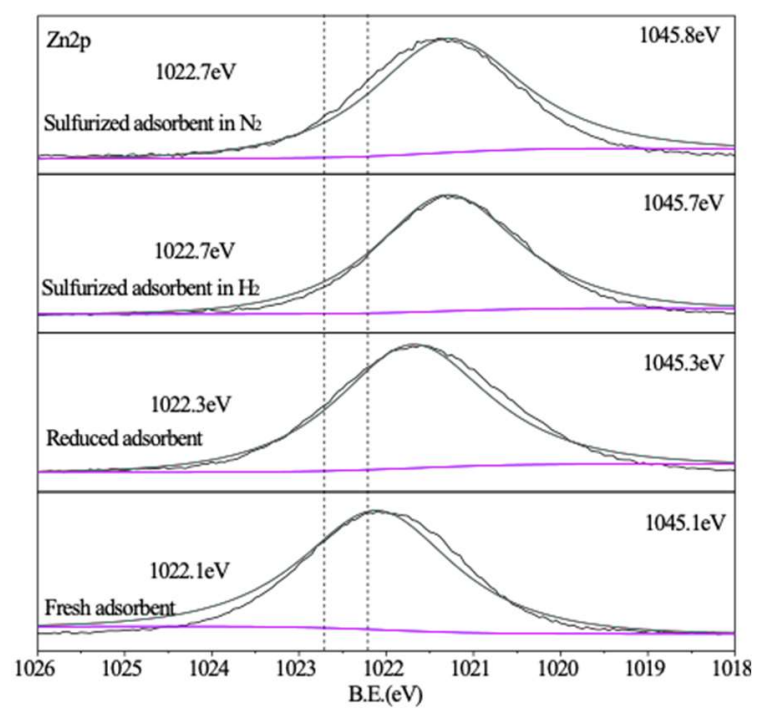

(d)

Figure 6. XPS spectra of Ni and Zn elements (a) C; (b) S; (c) Ni; (d) Zn.

For Sulfur XPS spectra in Figure $6 \mathrm{~b}$, peaks of $162.4 \mathrm{eV}$ and $163.6 \mathrm{eV}$ are attributed to the peaks of S2p spectra of ZnS and NiS, respectively, which proves the existence of intermediate species $\mathrm{NiS} x[28,29]$. According to Babich and Moulijin's mechanism, the transient state NiS $x$ will react with $\mathrm{H}_{2}$ immediately, therefore, the peaks of NiS $x$ cannot be detected in XRD results.

Normally, XPS spectra of Nickel-containing compounds consist of a main photo-peak as well as an associated satellite peak. The latter always locates at a binding energy which is 6 to $8 \mathrm{eV}$ higher than the main peak. Figure $6 \mathrm{c}$ presents Ni2p3/2 photo-peaks of the Ni-containing compounds. In the figure, the Ni2p3/2 spectrum $852.5( \pm 0.2) \mathrm{eV}$ of nickel metal is not detected for the four adsorbents [30]. This indicates that $\mathrm{NiO}$ is hard to be reduced by hydrogen. Peaks of $855.1 \mathrm{eV}$ and $861.5 \mathrm{eV}$ of the 
fresh adsorbents are attributed to the main peak and the satellite peak of the $\mathrm{Ni2p} 3 / 2$ spectra of $\mathrm{NiO}$, respectively. The peaks centered at bind energy of $873.0 \mathrm{eV}$ and $879.7 \mathrm{eV}$ are attributed to Ni2p1/2 spectra of $\mathrm{NiO}$ [31]. In the XPS spectra of spent adsorbent, a peak at bind energy $853.3 \mathrm{eV}$ appears after desulfurization in both nitrogen and hydrogen, corresponding to $\mathrm{Ni}$ in the sulfided form $\mathrm{NiS} x$. Besides, small increments of binding energy of Ni2p3/2 photo-peaks are observed for the reduced and spent adsorbent. This suggests the enhancement of the chemical interaction between $\mathrm{NiO}$ and the support $\mathrm{ZnO}-\mathrm{Al}_{2} \mathrm{O}_{3}-\mathrm{SiO}_{2}$.

Figure $6 \mathrm{~d}$ shows the $\mathrm{Zn2p}$ spectra of different adsorbents. The peak at bind energy of $1022.1 \mathrm{eV}$ in fresh adsorbent is assigned to $\mathrm{Zn2p} 3 / 2$, and the peak at bind energy of $1045.25 \mathrm{eV}$ is attributed to $\mathrm{Zn} 2 \mathrm{p} 1 / 2$. After desulfurization, the bind energy of $\mathrm{Zn} 2 \mathrm{p}$ increases $1.2 \mathrm{eV}$, indicating that sulfur atom reacted with $\mathrm{ZnO}$ to form $\mathrm{ZnS}$. Moreover, for S $2 \mathrm{p}$ spectra (Figure 5), the peak at $162.4 \mathrm{eV}$ is attributed to $\mathrm{ZnS}$ group, also indicating sulfur atom transfers to $\mathrm{ZnS}$ from $\mathrm{ZnO}$.

\subsection{RADS Performance at Different Temperatures}

Figure 7 is a comparison of the desulfurization effects of unreduced adsorbents at $420{ }^{\circ} \mathrm{C}, 400{ }^{\circ} \mathrm{C}$, $350{ }^{\circ} \mathrm{C}$, and $300^{\circ} \mathrm{C}$. The former two reactions have little difference on sulfur removal rate from the beginning to the end, mainly because a $20^{\circ} \mathrm{C}$ temperature difference does not impact RADS greatly. The reaction at $350{ }^{\circ} \mathrm{C}$ performs a reduction of sulfur removal at the beginning, and then keep a high sulfur removal rate as the former two reactions. It suggests that the reaction temperature may affect the activation of adsorbent at the beginning of RADS.

For the RADS process which happened at $300{ }^{\circ} \mathrm{C}$, the curve decreases first and then increase. This special trend does not accord with the usual decreasing activity found in most of RADS processes. Especially, at $300{ }^{\circ} \mathrm{C}$, the strong rising trend of desulfurization capacity is observed after the volume of feed reaching $22 \mathrm{~mL}-\mathrm{G} / \mathrm{g}-\mathrm{A}$. This phenomenon inspires us to design three experiments to pretreat the adsorbents used in the experiments at $300^{\circ} \mathrm{C}$.

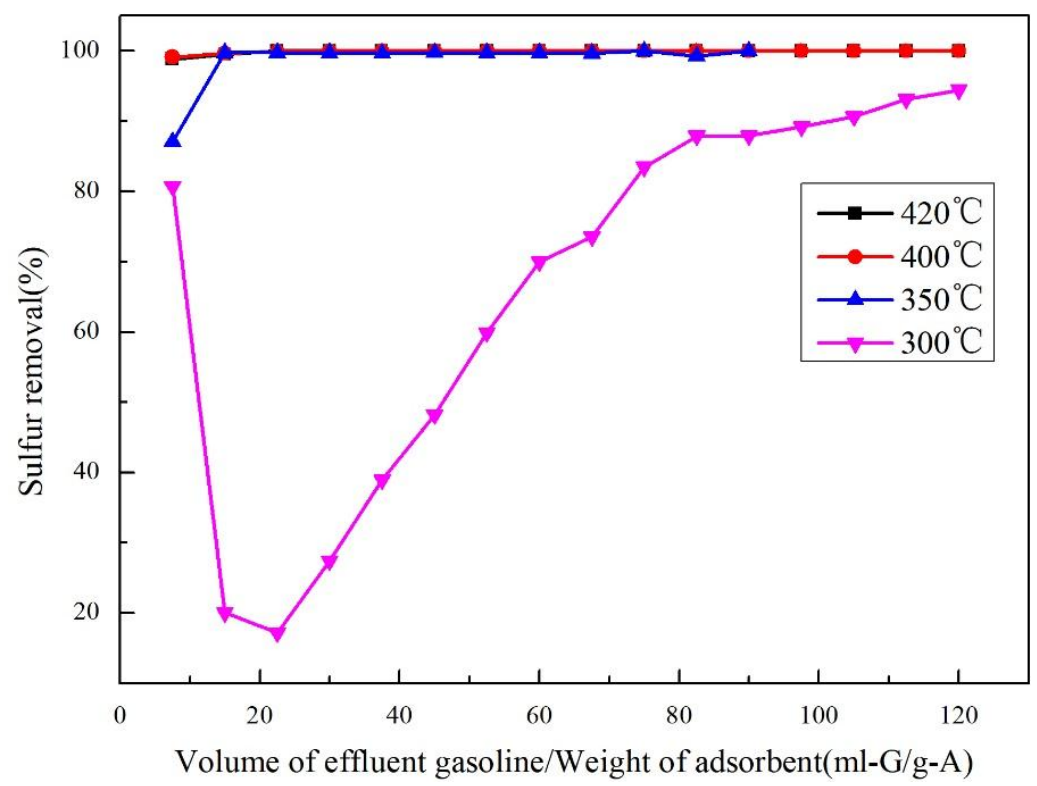

Figure 7. Desulfurization performance of unreduced adsorbents at different temperatures.

\subsection{Effects of Pretreatments on RADS Performance}

Figure 8 investigates the influence of different pretreatment methods of adsorbent on sulfur removal at $300{ }^{\circ} \mathrm{C}$. Different pretreatment methods were compared to each other. For example, the black line (case A) presents the sulfur removal of the adsorbent pretreated in $\mathrm{H}_{2}$ for $2 \mathrm{~h}$ at $420^{\circ} \mathrm{C}$ in advance. The red line (case $\mathrm{B}$ ) is the sulfur removal of the adsorbent pretreated in $\mathrm{H}_{2}$ along with 
n-hexane at $420^{\circ} \mathrm{C}$ for $2 \mathrm{~h}$. The blue line (case C) means the adsorbent was pretreated for $2 \mathrm{~h}$ in $\mathrm{H}_{2}$ along with model gasoline at $420^{\circ} \mathrm{C}$ for $2 \mathrm{~h}$.

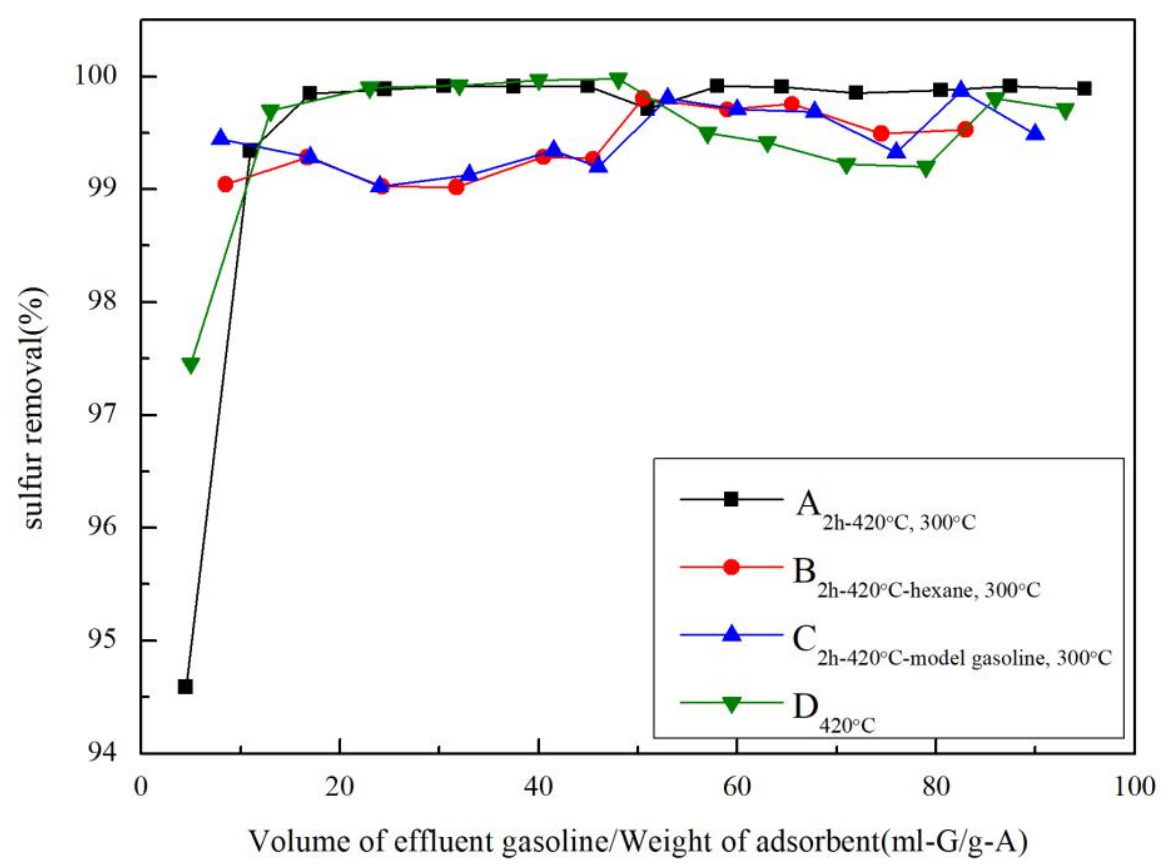

Figure 8. Desulfurization curves of unreduced adsorbents under different conditions: (A) pretreated for $2 \mathrm{~h}$ in $\mathrm{H}_{2}$ at $420^{\circ} \mathrm{C}$; (B) pretreated for $2 \mathrm{~h}$ in $\mathrm{H}_{2}$ along with n-hexane at $420^{\circ} \mathrm{C}$; (C) pretreated for $2 \mathrm{~h}$ in $\mathrm{H}_{2}$ along with model gasoline at $420^{\circ} \mathrm{C}$ (D) without pretreatment at $420^{\circ} \mathrm{C}$ reaction temperature.

In Figure 8, some differences on the initial sulfur removal of various pretreated adsorbents are observed. The process of reaction can be divided into two parts at the point $8 \mathrm{~mL}-\mathrm{G} / \mathrm{g}-\mathrm{A}$. During the part after this point, there seems no difference in the sulfur removal capacity between the pretreated adsorbents adopted in case A, B, C, and adsorbents without any pretreatment in case D. Compared the sulfur removal rate of adsorbents without pretreatment at $300{ }^{\circ} \mathrm{C}$ shown in Figure 7 with the desulfurization performance of case $\mathrm{A}$ at the same reaction temperature, a positive effect of pretreatment in hydrogen for $2 \mathrm{~h}$ on sulfur removal should be convincing. However, during the process before the feed reaching $10 \mathrm{~mL}-\mathrm{G} / \mathrm{g}-\mathrm{A}$, the sulfur removal rate indicated by the curve of case A is slightly lower compared with which of case D. Interestingly, with the participation of n-hexane during the process of pretreatment, the drop of sulfur removal at the beginning of RADS that occurs in case $A$ disappears in case $B$ and $C$. The function of $n$-hexane is considered while discussing the various results of different types of pretreatments in case $\mathrm{A}, \mathrm{B}$, and $\mathrm{C}$ at the beginning of the process. It is assumed that n-hexane reacts with the adsorbent, during which some carbon-metal bond is formed. This type of bond may promote the electric charge transfer on the surface of adsorbent. As a result, the desulfurization capacity of the adsorbent is enhanced regardless of the much lower reaction temperature.

From the analyses above, it can be concluded that the participation of hydrogen and n-hexane during the process of pretreatment conducted at $420^{\circ} \mathrm{C}$ both contribute to the improvement on sulfur removal rate under the reaction temperature of $300^{\circ} \mathrm{C}$. The activation mechanism of the pretreatments on adsorbents will be researched in our future work. 


\section{Materials and Methods}

\subsection{Adsorbent Preparation and Feedstock Properties}

All chemicals used for preparation of adsorbents are of analytical grade. In this study, the feedstock is prepared by adding thiophene to sulfur-free n-hexane with a sulfur concentration of 800 ppmw. The support $\mathrm{ZnO}-\mathrm{Al}_{2} \mathrm{O}_{3}-\mathrm{SiO}_{2}$ was prepared by the co-precipitation method. A mixed solution of $\mathrm{Al}\left(\mathrm{NO}_{3}\right)_{3} \cdot 9 \mathrm{H}_{2} \mathrm{O}$ and $\mathrm{Zn}\left(\mathrm{NO}_{3}\right)_{2} \cdot 6 \mathrm{H}_{2} \mathrm{O}$ is added into a mixed solution of $\mathrm{Na}_{2} \mathrm{SiO}_{3} \cdot 9 \mathrm{H}_{2} \mathrm{O}(0.2 \mathrm{~mol} / \mathrm{L})$ and $\mathrm{Na}_{2} \mathrm{CO}_{3}(0.2 \mathrm{~mol} / \mathrm{L})$ at a rate of $15 \mathrm{~mL} / \mathrm{min}$ under $20^{\circ} \mathrm{C}$, followed by aging in the same environment for $2 \mathrm{~h}$. In the first $50 \mathrm{~min}$ of the aging process, the supernatant is replaced with the same volume of water. After filtration treatment, about $3.5 \mathrm{~L}$ of deionized water is used to wash the precipitation until the $\mathrm{pH}$ of suspension ranges from 5.5 to 6.0. Then the residue will be dried at $120{ }^{\circ} \mathrm{C}$ in atmosphere for $12 \mathrm{~h}$, followed by calcination at some temperature in a muffle roaster for $4 \mathrm{~h}$. The preparation of support $\mathrm{ZnO}-\mathrm{Al}_{2} \mathrm{O}_{3}-\mathrm{SiO}_{2}$ is finished.

Solutions of $\mathrm{Ni}\left(\mathrm{NO}_{3}\right)_{2}$ were mixed with the above support and stirred for two hours. And then, a solution of anhydrous sodium $(0.2 \mathrm{~mol} / \mathrm{L})$ was added into the mixed solution at a rate of $15 \mathrm{~mL} / \mathrm{min}$ under $20^{\circ} \mathrm{C}$. Then an excessive dose of $\mathrm{Na}_{2} \mathrm{CO}_{3}$ was added into the solution which converted $\mathrm{Ni}^{2+}$ into corresponding deposits followed by a two-hour stirring. Next the emulsion was filtrated with deionized water until the filter liquid displayed as neutral. The filter cake left was dried at $120^{\circ} \mathrm{C}$ before calcinated in a muffle oven at $500{ }^{\circ} \mathrm{C}$ for $2 \mathrm{~h}$. After cooling to the normal temperature, the filter cake was ground to 120 mesh. Finally, the preparation of adsorbents was finished.

\subsection{Characterization of Adsorbents}

A Bruker D8 Advance X-ray diffractometer (Bruker, Karlsruhe, Germany) is used to characterize the crystalline structures of the adsorbents through X-ray diffraction (XRD) with a $\mathrm{Cu} \mathrm{K} \alpha=0.154 \mathrm{~nm}$ monochromatized radiation source, operating at $40 \mathrm{kV}$ and $100 \mathrm{~mA}$. Autochem II 2920 (Micromeritics, Norcross, GA, USA) is used to detect the Temperature programmed reduction (TPR) of adsorbents. And the multi-function photoelectron spectrometer (ESCALAB 250Xi) (Thermo Fisher Scientific, Waltham, MA, USA) is deployed to characterize the X-ray photoelectron spectroscopy (XPS). An EDXA energy dispersive spectrometer (EDS) (EDAX Inc., Mahwah, MA, USA) is used to characterize the elements distributions of adsorbents.

\subsection{Sulfur Adsorption Experiments}

The desulfurization experiments were carried out in a continuous micro fixed-bed reactor [22-24]. A total of $3 \mathrm{~g}$ of adsorbent in the oxidized form was loaded into the reactor per run. The sorbent was reduced by hydrogen at a flow rate of $140 \mathrm{~mL} / \mathrm{min}$ under $2.0 \mathrm{MPa}$ and $440{ }^{\circ} \mathrm{C}$ for $2 \mathrm{~h}$ followed by the pumping of the model fuel. The desulfurization products were collected periodically in a beaker to analyze sulfur content. The various experimental conditions are showed in Table 1.

Table 1. Experimental conditions of desulfurization process.

\begin{tabular}{|c|c|c|c|}
\hline \multicolumn{2}{|c|}{ Reduction } & $\begin{array}{c}\text { Temp. } /{ }^{\circ} \mathrm{C} \\
\text { Hydrogen pressure } / \mathrm{MPa}\end{array}$ & $\begin{array}{l}440 \\
2.0\end{array}$ \\
\hline \multirow{2}{*}{$\begin{array}{c}\text { Adsoption } \\
\text { desulfurization }\end{array}$} & In $\mathrm{H}_{2}$ & $\begin{array}{c}\text { Temp. } /{ }^{\circ} \mathrm{C} \\
\text { Hydrogen pressure } / \mathrm{MPa} \\
\text { Weight hourly space velocity }(\mathrm{WHSV}) / \mathrm{h}^{-1} \\
\mathrm{H}_{2} \text { volume/Gasoline weight }(\mathrm{mL} / \mathrm{g})\end{array}$ & $\begin{array}{c}300,350,400,420 \\
2.9 \\
9.9 \\
70\end{array}$ \\
\hline & In $\mathrm{N}_{2}$ & $\begin{array}{c}\text { Temp. } /{ }^{\circ} \mathrm{C} \\
\text { Nitrogen pressure } / \mathrm{MPa} \\
\text { Weight hourly space velocity }(\mathrm{WHSV}) / \mathrm{h}^{-1} \\
\mathrm{~N}_{2} \text { volume/Gasoline weight }(\mathrm{mL} / \mathrm{g})\end{array}$ & $\begin{array}{l}420 \\
2.9 \\
9.9 \\
70\end{array}$ \\
\hline
\end{tabular}


The sulfur removal efficiency is defined as the following equation [32]:

$$
R_{\mathrm{S}}(\%)=\frac{C_{0}-C_{t}}{C_{0}} \times 100
$$

where $R_{S}$ is the sulfur removal efficiency in the fuel (\%), $C_{0}$ is the sulfur concentration of feedstock $(\mu \mathrm{g} / \mathrm{g}), C_{t}$ is the sulfur content of product at any time $(\mu \mathrm{g} / \mathrm{g})$.

The sulfur concentrations of model gasoline are characterized by an Antek 9000 total sulfur analyzer (Antek, North Arlington, TX, USA).

\section{Conclusions}

The RADS process was conducted over the $\mathrm{NiO} / \mathrm{ZnO}-\mathrm{Al}_{2} \mathrm{O}_{3}-\mathrm{SiO}_{2}$ sorbent, and the effect of reaction atmospheres are discussed and compared. The RADS process could happen in $\mathrm{N}_{2}$ without the presence of $\mathrm{H}_{2}$, which proves that $\mathrm{NiO}$ performs as an active RADS component. XRD, TPR, and XPS results showed that strong metal-support interactions between $\mathrm{NiO}$ and the support are formed. This makes $\mathrm{NiO}$ more difficult to be reduced. The desulfurization performance of the adsorbent at $300{ }^{\circ} \mathrm{C}$ indicated that $\mathrm{NiO}$ could also perform a good desulfurization ability, and the formation of $\mathrm{NiS} x$ may promote the desulfurization process on the surface of the adsorbent. At last, the activation performances of different pretreatment on RADS process were evaluated. The participation of hydrogen and n-hexane in pretreatment conducted at $420{ }^{\circ} \mathrm{C}$ could active the adsorbent in the beginning of RADS and improve the sulfur removal rate under the reaction temperature of $300^{\circ} \mathrm{C}$.

Author Contributions: Writing—review and editing, F.J. and H.L.; Writing—original draft preparation, M.W.; data curation, T.W.

Funding: This research received no external funding.

Acknowledgments: The support from the Fundamental Research Funds for the Central Universities of China is gratefully acknowledged.

Conflicts of Interest: The authors declare no conflict of interest.

\section{References}

1. Oyama, S.T.; Gott, T.; Zhao, H.; Lee, Y.K. Transition metal phosphide hydroprocessing catalysts: A review. Catal. Today 2009, 143, 94-107. [CrossRef]

2. Kim, J.H.; Ma, X.; Zhou, A.; Song, C. Ultra-deep desulfurization and denitrogenation of diesel fuel by selective adsorption over three different adsorbents: A study on adsorptive selectivity and mechanism. Catal. Today 2006, 111, 74-83. [CrossRef]

3. Jeon, H.J.; Chang, H.K.; Kim, S.H.; Kim, J.N. Removal of Refractory Sulfur Compounds in Diesel Using Activated Carbon with Controlled Porosity. Energy Fuels 2009, 23, 2537-2543. [CrossRef]

4. Xiao, J.; Li, Z.; Liu, B.; Xia, Q.; Yu, M. Adsorption of Benzothiophene and Dibenzothiophene on Ion-Impregnated Activated Carbons and Ion-Exchanged Y Zeolites. Energy Fuels 2008, 22, 3858-3863. [CrossRef]

5. Khare, G.P. Desulfurization Process and Novel Bimetallic Sorbent Systems for Same. U.S. Patent 6,531,053, 11 March 2003.

6. Khare, G.P. Process for the Production of a Sulfur Sorbent. U.S. Patent 6,184,176, 6 February 2001.

7. Turaga, U.T.; Gislason, J.J. Desulfurization and Novel Compositions for Same. U.S. Patent 7,201,839, 10 April 2007.

8. Xu, W.; Xiong, C.; Zhou, G.; Zhou, H. Removal of sulfur from FCC gasoline by using $\mathrm{Ni} / \mathrm{ZnO}$ as adsorbent. Acta Pet. Sin. 2008, 24, 739-743. [CrossRef]

9. Wang, T.; Wang, X.; Gao, Y.; Su, Y.; Miao, Z.; Wang, C.; Lu, L.; Chou, L.; Gao, X. Reactive adsorption desulfurization coupling aromatization on $\mathrm{Ni} / \mathrm{ZnO}-\mathrm{Zn}_{6} \mathrm{Al}_{2} \mathrm{O}_{9}$ prepared by $\mathrm{ZnxAly}(\mathrm{OH})_{2}\left(\mathrm{CO}_{3}\right) \mathrm{z} \cdot \mathrm{xH}_{2} \mathrm{O}$ precursor for FCC gasoline. J. Energy Chem. Res. 2015, 24, 503-511. [CrossRef]

10. Fan, J.; Gang, W.; Yu, S.; Xu, C.; Zhou, H.; Zhou, G.; Gao, J. Research on Reactive Adsorption Desulfurization over $\mathrm{Ni} / \mathrm{ZnO}-\mathrm{SiO}_{2}-\mathrm{Al}_{2} \mathrm{O}_{3}$ Adsorbent in a Fixed-Fluidized Bed Reactor. Ind. Eng. Chem. Res. 2010, 49, 8450-8460. [CrossRef] 
11. Li, H.; Dong, L.; Zhao, L.; Xu, C. Enhanced Adsorption Desulfurization Performance over Mesoporous ZSM-5 by Alkali Treatment. Ind. Eng. Chem. Res. 2017, 56, 3813-3821. [CrossRef]

12. Timko, M.T.; Wang, J.A.; Burgess, J.; Kracke, P.; Gonzalez, L.; Jayee, C.; Fischere, D.A. Roles of surface chemistry and structural defects of activated carbons in the oxidative desulfurization of benzothiophenes. Fuel 2016, 163, 223-231. [CrossRef]

13. Wang, W.; Li, X.; Zhang, Y.; Tang, M. Strong metal-support interactions between Ni and ZnO particles and their effect on the methanation performance of Ni/ZnO. Catal. Sci. Technol 2017, 7, 4413-4421. [CrossRef]

14. Babich, I.V.; Moulijn, J.A. Science and technology of novel processes for deep desulfurization of oil refinery streams: a review. Fuel 2003, 82, 607-631. [CrossRef]

15. Huang, L.; Wang, G.; Qin, Z.; Dong, M.; Du, M.; Ge, H.; Li, X.; Zhao, Y.; Zhang, J.; Hu, T.; et al. In situ XAS study on the mechanism of reactive adsorption desulfurization of oil product over $\mathrm{Ni} / \mathrm{ZnO}$. Appl. Catal. B 2011, 106, 26-38. [CrossRef]

16. Bezverkhyy, I.; Safonova, O.V.; Afanasiev, P.; Bellat, J.P. Reaction between Thiophene and Ni Nanoparticles Supported on $\mathrm{SiO}_{2}$ or ZnO: In Situ Synchrotron X-ray Diffraction Study. J. Phys. Chem. C 2009, 113. [CrossRef]

17. Okamoto, H.J. Phase Equilib. Diffusion 2009, 30, 123.

18. Ryzhikov, A.; Bezverkhyy, I.; Bellat, J.P. Reactive adsorption of thiophene on Ni/ZnO: Role of hydrogen pretreatment and nature of the rate determining step. Appl. Catal. B 2008, 84, 766-772. [CrossRef]

19. Bezverkhyy, I.; Ryzhikov, A.; Gadacz, G.; Bellat, J.P. Kinetics of thiophene reactive adsorption on $\mathrm{Ni} / \mathrm{SiO}_{2}$ and $\mathrm{Ni} / \mathrm{ZnO}$. Catal. Today 2008, 130, 199-205. [CrossRef]

20. Gao, Y.; Fang, X.; Cheng, Z. A comparative study on the ex situ and in situ presulfurization of hydrotreating catalysts. Catal. Today 2010, 158, 496-503. [CrossRef]

21. Jin, F.Y.; Long, H.Y.; Song, W.C.; Xiong, G.; Guo, X.W.; Wang, X.S. Active Phase of a $\mathrm{NiSO}_{4} \mathrm{Catalyst}$ Supported on $\gamma-\mathrm{Al}_{2} \mathrm{O}_{3}$ during in Situ Self-Sulfidation for Selective Hydrodesulfurization. Energy Fuels 2013, 27, 3394-3399. [CrossRef]

22. Ju, F.; Liu, C.; Meng, C.; Gao, S.; Ling, H. Reactive Adsorption Desulfurization of Hydrotreated Diesel over a Ni/ZnO-Al $\mathrm{O}_{3}-\mathrm{SiO}_{2}$ Adsorbent. Energy Fuels 2015, 29, 6057-6067. [CrossRef]

23. Ju, F.; Liu, C.; Li, K.; Meng, C.; Gao, S.; Ling, H. Reactive adsorption desulfurization of FCC gasoline over a Ca-Doped $\mathrm{Ni}-\mathrm{ZnO} / \mathrm{Al}_{2} \mathrm{O}_{3}-\mathrm{SiO}_{2}$ adsorbent. Energy Fuels 2016, 30, 6688-6697. [CrossRef]

24. Ju, F.; Wang, M.; Luan, H.; Du, P.; Tang, Z.; Ling, H. Reactive adsorption desulfurization of $\mathrm{NiO}$ and $\mathrm{Ni}^{0}$ over $\mathrm{NiO} / \mathrm{ZnO}-\mathrm{Al}_{2} \mathrm{O}_{3}-\mathrm{SiO}_{2}$ adsorbents: role of hydrogen pretreatment. RSC Adv. 2018, 8, 33354-33360. [CrossRef]

25. Rahbar, S.F.; Meshkani, F.; Rezaei, M. Ultrasound assisted co-precipitation synthesis and catalytic performance of mesoporous nanocrystalline $\mathrm{NiO}-\mathrm{Al}_{2} \mathrm{O}_{3}$ powders. Ultrason. Sonochem. 2017, 34, 436-447. [CrossRef] [PubMed]

26. Zieliński, J. Morphology of nickel/alumina catalysts. J. Catal. 1982, 76, 157-163. [CrossRef]

27. Greczynski, G.; Hultman, L. Reliable determination of chemical state in x-ray photoelectron spectroscopy based on sample-work-function referencing to adventitious carbon: Resolving the myth of apparent constant binding energy of the C 1s peak. Appl. Surf. Sci. 2018, 451, 99-103. [CrossRef]

28. Herron, S.M.; Lawal, Q.O.; Bent, S.F. Polysulfide ligand exchange on zinc sulfide nanocrystal surfaces for improved film formation. Appl. Surf. Sci. 2015, 359, 106-113. [CrossRef]

29. Smart, R.S.C.; Skinner, W.M.; Gerson, A.R. Xps of sulphide mineral surfaces: metal-deficient, polysulphides, defects and elemental sulphur. Surf. Interface Anal. 1999, 28, 101-105. [CrossRef]

30. Ertl, G.; Hierl, R.; Knözinger, H.; Thiele, N.; Urbach, H.P. XPS study of copper aluminate catalysts. Appl. Surf. Sci. 1980, 5, 49-64. [CrossRef]

31. Nesbitt, H.W.; Legrand, D.; Bancroft, G.M. Interpretation of Ni2p XPS spectra of Ni conductors and Ni insulators. Phys. Chem. Miner. 2000, 27, 357-366. [CrossRef]

32. Seader, J.D.; Henley, E.J. Separation Process Principles; Wiley: New York, NY, USA, 1998.

(C) 2019 by the authors. Licensee MDPI, Basel, Switzerland. This article is an open access article distributed under the terms and conditions of the Creative Commons Attribution (CC BY) license (http:/ / creativecommons.org/licenses/by/4.0/). 